УДК 502.45

\title{
Аержавні цільові екологічні програми: сутність та шляхи формування на регіональному рівні
}

\author{
О.М. СКАКААЬСЬКИЙ \\ Аніпропетровський регіональний інститут Аержавного управління \\ Національної акалемії Аержавного управління при Презилентові України, \\ м. Аніпропетровськ, Україна, E-mail: u.promeco@gmail.com
}

\begin{abstract}
Авторське резюме
У статті розглядаються актуальні питання сутності та шляхів формування регіональних цільових екологічних програм.

Автор виходить 3 тези, що незважаючи на науково-технічний прогрес, сучасне суспільство залишається невід'ємним компонентом природного середовища, яке нині значно трансформовано і постійно втрачає можливості до відновлення та саморозвитку. Використання території України сьогодні характеризується значними диспропорціями, надзвичайно високим, економічно та екологічно необгрунтованим рівнем промислового та сільськогосподарського освоєння земель, урбанізаційними змінами ландшафтів тощо. Процес становлення України як демократичної, правової, соціальної держави, ії інтеграція до європейської спільноти передбачають запровадження та реалізацію сучасних світових підходів до природного середовища, як частини життєвого простору людини.

Одним із напрямків такої діяльності є розробка і послідовне здійснення цілеспрямованої екологічної політики, яка відповідала б світовим нормам імплементації такого виду галузевого та територіально-адміністративного планування, як державні комплексні цільові програми.

У цьому зв'язку набуває гострої актуальності дослідження процесу формування регіональних цільових екологічних програм згідно з природоохоронними пріоритетами та їх реалізації на місцевому рівні. Особлива увага до екологічно трансформованих регіонів, зокрема Дніпропетровщини, де широкомасштабне промислове використання природних ресурсів, їх поступове виснаження і руйнування створило загрозливу ситуацію зі станом природного середовища.

Дослідження в статті стосуються механізму формування та реалізації регіональної природоохоронної політики в межах державних цільових екологічних програм.

Ключові слова: екологічна політика, програмно-цільовий метод, державна цільова програма, регіональна природоохоронна політика, цільова екологічна програма, регіональні екологічні програми.
\end{abstract}

\section{Government targeted environmental programs: the nature and ways of forming the regional level}

\author{
O.M. SKAKAL`SKYJ \\ Dnipropetrovsk regional institute of public administration of National \\ academy for public administration under the President of Ukraine, \\ Dnipropetrovsk, Ukraine, E-mail: u.promeco@gmail.com
}

\begin{abstract}
This article is diidicated topical issues of nature and ways of forming a regional environmental programs. The author comes out with the thesis that despite scientific and technological progress, modern society remains an integral component of the natural environment, which now greatly transformed and constantly loses its ability to recover and self-development. The using of the territory of Ukraine today is characterized by considerable disparities be an extraordinarily high, economically and ecologically wrong level of
\end{abstract}

(C) O.М. Скакальський, 2015 
industrial and agricultural development, urbanìsational changes in landscapes, etc.

The process of formation of a new Ukraine as a democratic, legal, social State and its integration into the European Community provide the introduction and implementation of modern international approaches to the natural environment, as part of the living space of the person. One of the directions of this activity is the development and consistent implementation of targeted environmental policy to match world standards the implementation of such kind of territorial-administrative planning, as the State complex target program. In this connection takes the acute relevance of the study of the process of the formation of regional environmental programs, according to the environmental priorities and implementation at the local level. The ecological transformed regions are looked through a special attention to, in particular in the Dnipropetrovsk region, where large scale industrial of natural resources are using, that has created a threatening situation with the condition of the natural environment. In this article the mechanism of the formation and implementation of the regional environmental policy programs is constructed at the State environmental level.

Keywords: environmental policy, program-target method, state target program, regional environmental policy, target environmental program, regional environmental programs.

Аналіз досліджень і публікацій. Значний внесок у розробку теоретичних i практичних проблем програмування соціально-економічного розвитку, що розглянуті автором, внесли такі науковці як: В. Бєсєдін, В. Будавей, Л. Дідківська, В. Керецман, В. Кінг, Д. Клиланд, М. Кульчицький, О. Макарова, Т.Максимова, В.Мамонова, Б.Райзберг, Д. Стеченко та ін. Науково-теоретичне підгрунтя дослідження у галузі державного управління природоохоронною діяльністю в Україні становлять також праці В. Б. Авер'янова, Г. В. Білявського, Ю. П. Битяка, А. П. Гетьмана, Л.В. Коваля, Б. М. Лазарєва, Л. Я. Окорокової, М. П. Стеценка, В. Я. Шевчука, В. В. Цвєткова, Ю. С. Шемшученка та ін., що допомогли автору в екстраполяції загальнодержаних рішень з екологічної політики на регіональний рівень.

Об'єктом дослідження в роботі є регіональні екологічні цільові програми, що діють в Дніпропетровській області.

Предметом дослідження виступають організаційні, функціональні та правові аспекти діяльності органів місцевого самоврядування та виконавчої влади Дніпропетровської області щодо управління процесом створення та реалізації регіональних екологічних програм.

Мета дослідження полягає в тому, щоб розкрити зміст державного управління процесом природоохоронної діяль- ності через державні екологічні програми , визначити особливості їх реалізації органами виконавчої влади, місцевого самоврядування на регіональному рівні. Виходячи із визначеної мети, в статті поставлено такі основні завдання:

- дати оцінку соціально-економічним процесам, що відбуваються в Україні та їх впливу на природоохоронну політику держави;

- розглянути програмно-цільовий метод планування та його використання в практичній природоохоронній діяльності держави;

- визначити сукупність державних цільових екологічних програм та систему відповідальних за них державних органів влади;

- розкрити функції та компетенції органів виконавчої влади, місцевого самоврядування відповідно до регіональних екологічних програм, розглянути управлінські механізми їх реалізації;

- сформулювати висновки дослідження організаційно-правових засад управління процесом реалізації регіональних екологічних програм у Дніпропетровській області;

- викласти рекомендації щодо шляхів реалізації актуальних завдань удосконалення природоохоронної політики на регіональному рівні.

Виклад основного матеріалу. Сучасний стан економіки України характери- 
зується наявністю загальноекономічної кризи, що спричинена рядом внутрішніх і зовнішніх факторів: військовими діями на Донбасі, реформами ринкової економіки, децентралізацією влади, загальносвітовим впливом конкурентної ринкової економіки та загостренням геополітичного протистояння тощо.

Україна отримала у спадщину від $\mathrm{Pa}$ дянського Союзу диспропорційну структуру економіки з перевагою у ВВП продукції воєнно-промислового комплексу та добувної промисловості, оскільки була спрямована на обслуговування загальносоюзних потреб. В країні відсутні ресурсні можливості для подальшого нарощування видобутку нафти й газу, що робить їі економіку залежною від імпорту цього виду природних ресурсів. Така деформована галузева структура економіки України поглиблює також існуючу диференціацію між регіонами у рівнях виробництва промислової та сільськогосподарської продукції. Окрім того, набули деструктивних розмірів диспропорціі вторинної хвилі внутрішніх економічних змін, так званого реформування 90-х pp., що можна порівняти з етапом становлення «дикого» капіталізму. Внаслідок цих трансформацій в Україні відбулося значне фізичне скорочення виробництва та інвестиційної діяльності, набула поширення інфляція, остаточно порушилися господарські зв'язки.

Нова модель економічного прогресу України може спрацювати на стабільний розвиток лишень шляхом поетапного здійснення цілеспрямованої, науково обгрунтованої програми виходу 3 кризи при поєднанні регулюючого впливу державних органів на економіку і запровадження ринкових відносин. Ключовим чинником такого розвитку економічної сфери має стати держава, яка, не втручаючись у діяльність господарських суб'єктів, зможе управляти ринком і підтримувати його, стримувати негативні тенденції через відповідні юридичні важелі. Звідси планування є пріоритетною функцією управління, що складається з підготовки різних варіантів управлінських рішень у вигляді прогнозів, проектів, програм і планів, що включає науково обгрунтоване визначення цілей, показників, завдань, термінів тощо[11].

Процеси стабілізації економіки України вимагають впровадження такого виду галузевого та територіально-адміністративного планування, як державні комплексні цільові програми (ДЦКП), які можуть діяти в умовах різних форм власності. Такі ДЦКП пов'язані за ресурсами, виконавцями і термінами здійснення комплексу завдань у галузі державного будівництва, науково-технічного, економічного, інвестиційного, екологічного розвитку України. Для програмно-цільового методу характерне те, що він забезпечує реалізацію одночасно таких двох типів інтеграції соціально-економічних і науково-технічних процесів: просторова (географічна) та часова інтеграція. За першої - вимагається об'єднати зусилля суб'єктів, що належать до різних галузей, регіонів або форм власності, за другої - створити умови для досягнення чіткої послідовності і єдності різних етапів загального процесу руху до кінцевої мети. Тому Державні цільові комплексні програми згідно зі статтею 1 закону визначаються як «... комплекс взаємопов'язаних завдань i заходів, які спрямовані на розв'язання найважливіших проблем розвитку держави, окремих галузей економіки або адміністративно-територіальних одиниць, здійснюються 3 використанням коштів Державного бюджету України та узгоджені за строками виконання, складом виконавців, ресурсним забезпеченням» [2].

Класифікація державних цільових комплексних програм здійснюється за такими основними ознаками.

1. За рівнем, за складом, за сферою впливу та реалізації (міждержавні, державні, міжгалузеві, галузеві, міжрегіональні, регіональні, локальні).

2. За характером і специфікою проблем і цілей.

3. За термінами виконання програми поділяють на: довгострокові (розраховані на період 5-10 років); середньострокові (1-5 років); короткострокові (до 1 року). Ця класифікація зумовлена 
характером цілей, на досягнення яких спрямовано програму, довгострокові програми спрямовано на досягнення стратегічних цілей. В Україні ДЦКП розробляються і реалізуються згідно 3 постановами Верховної Ради, указами Президента, розпорядженнями Кабінету Міністрів. Розробка та реалізація державних цільових комплексних програм потребує виконання певної сукупності робіт (заходів), пов'язаних 3 технікоекономічним обгрунтуванням, плануванням, виробництвом, фінансуванням тощо [12].

Кожна ДЦКП, незалежно від їі складності, обсягів фінансування та масштабів робіт, має так званий життєвий цикл, що складається 3 етапів, фаз та підетапів, підфаз, протягом яких здійснюються роботи. Основним елементом організаційно-економічного механізму реалізації завдань кожної з ДЦКП є механізм державних замовлень через державний контракт - основні документи, які регулюють економічні, правові й організаційні відносини між державним замовником i виконавцем. Правовою підставою виконання державних цільових комплексних програм виступають:

- Закон України «Про державне прогнозування та розроблення програм економічного i соціального розвитку України» від 2000 р. [1].;

- Закон України «Про державні цільові програми» від 2012 р. [3].

Ці закони встановлюють правові, економічні та організаційні засади формування цілісної системи прогнозних і програмних документів економічного i соціального розвитку України, окремих галузей економіки та окремих адміністративно-територіальних одиниць як складової загальної системи державного управління. Цими законами встановлюється також загальний порядок розроблення, затвердження та виконання зазначених прогнозних i програмних завдань.

Враховуючи напружену екологічну ситуацію в Україні, значні трансформації природних екосистем ряду промислових центрально-східних регіонів, у загальному переліку ДЦКП значне місце займають екологічні комплексні програми. Метою розробки всіх екологічних програм (міждержавних, державних, peгіональних, місцевих) визначається проведення ефективної і цілеспрямованої діяльності з організації природоохоронних заходів, відповідно до ст. 6 Закону України «Про охорону навколишнього природного середовища» .

Управління у сфері охорони навколишнього природного середовища через ДЦКП можна поділити на два види за предметною ознакою: програми так званої прямої дії, що регулюють суспільні відносини саме в екологічній предметній cфері; з другого боку - ті програми, які охоплюють більш широке коло економічних, соціальних та інших відносин, але мають вплив на сферу охорони довкілля.

3 урахуванням проведеного аналізу всього переліку ДЦКП можна привести наступний список державних цільових екологічних програм (тобто програм першого виду - прямої дії, що чітко визначають їі цільове призначення), відповідальним виконавцем яких $€$ Міністерство екологічної безпеки та природних ресурсів.

1. Загальнодержавна програма формування національної екологічної мережі України на 2000-2015 роки.

2. Загальнодержавна програма охорони та відтворення довкілля Азовського і Чорного морів.

3. Державна науково-технічна програма розвитку топографо-геодезичної діяльності та національного картографування.

4. Комплексна програма реалізації на національному рівні рішень, прийнятих на Всесвітньому саміті зі сталого розвитку, на 2003-2015 роки.

5. Програма припинення виробництва та використання озоноруйнівних речовин на 2004-2030 роки.

6. Комплексна програма протизсувних заходів на 2005-2014 роки.

7. Загальнодержавна програма розвитку мінерально-сировинної бази України.

8. Державна цільова екологічна програма проведення моніторингу нав- 
колишнього природного середовища.

9. Державна цільова екологічна програма розвитку Криму («Екологічно безпечний Крим») на 2011-2015 роки [4]. Державні цільові екологічні програми (ДЦЕП) є свого роду багатокомпонентним інструментом, якому притаманні як адміністративно-контрольні, так і економічні важелі управління, за допомогою яких забезпечується пріоритетність організаційно-економічних механізмів державного регулювання екологічної політики України.

Згідно з Програмою соціально-економічного та культурного розвитку області на 2015 рік на Дніпропетровщині діють 9 регіональних екологічних цільових програм (РЦЕП).

1. Обласна комплексна програма поводження з відходами на 2006 - 2015 роки № 485-18/XXIII від 16.11.2001;

2. Програма охорони навколишнього природного середовища Дніпропетровської області на 2005 - 2015 роки № 495-24/IV від 24.12.2004;

3. Програма формування та розвитку національної екологічної мережі Дніпропетровської області на 2006 2015 роки № 768-33/IV від 22.03.2006;

4. Програма моніторингу довкілля Дніпропетровської області № 294-13/V від 04.12.2007;

5. Програма поліпшення екологічного стану Дніпропетровської області за рахунок зменшення забруднення довкілля основними підприємствами-забруднювачами на 2007 - 2015 роки № 29513/V від 04.12.2007;

6. Регіональна програма викорис тання порушених земель гірничодобувних підприємств у якості відновлюваних елементів екологічної мережі Криворізького залізорудного та Нікопольського марганцеворудного басейнів на 2010 2014 роки № 782-27/V від 22.03. 2010;

7. Регіональна програма «Ліси Дніпропетровщини» на 2011 - 2015 роки № 109-6/VI від 29.04.2011;

8. Довгострокова програма по вирішенню екологічних проблем Кривбасу та поліпшенню стану навколишнього природного середовища на 2011 - 2022 роки № 110-6/VI від 29 квітня 2011[10].
Оскільки питання природоохоронної діяльності в області знаходяться в компетенції різних державних органів, у територіально-адміністративній площині цими питаннями займаються інститути загальної компетенції: обласна рада народних депутатів та обласна державна адміністрація. Отримавши делеговані повноваження від обласної ради народних депутатів обласна державна адміністрація в особі Департаменту екології та природних ресурсів Дніпропетровська ОДА виступає відповідальною установою і державним замовником виконання РЦЕП. За загальною спеціалізацією місцеві екологічні програми Дніпропетровської області спрямовані на забез печення регіональної політики в сфері охорони навколишнього природного середовища інститутами загальної компетенції в частині виконання заходів за цільовими екологічними програмами спрямовані за наступними головними завданнями:

- розробка прогнозів соціально-економічного розвитку регіону по розділу «Охорона навколишнього природного середовища»;

- організація розробки природоохоронних програм та координація діяльності всіх учасників по їх виконанню;

- забезпечення координації управління та контролю за використанням та охороною природних ресурсів;

- підготовка рекомендацій (прогнозів) за напрямками розвитку природоохоронної діяльності;

- визначення напрямків розвитку міжгалузевих та міжрегіональних обласних зв'язків та зовнішньоекономічних відносин 3 питань охорони навколишнього природного середовища;

- організація формування та використання обласного фонду охорони навколишнього природного середовища за програмними напрямками і заходами;

- організація та проведення екологічної експертизи проектів, що включаються до виконання у програми із залученням громадськості тощо.

Фінансування заходів по всіх РЦЕП затверджується в обласному бюджеті на початку бюджетного періоду (за звичай, 
в січні місяці) і контролюється за етапами виконання та по завершенні року. Так обласним бюджетом на 2014 рік на впровадження 58 природоохоронних заходів, затверджених екологічних програм, було спрямовано 146,2 млн. грн., у складі видатків обласного бюджету [5].

Свої профільні (галузеві) завдання в виконанні РЦЕП мають і органи спеціальної компетенції управління охороною навколишнього природного середовища (Головне територіальне управління Держслужби 3 надзвичайних ситуацій, Обласне виробниче управління водного господарства, Дніпропетровське обласне управління лісового та мисливського господарства, Обласне управління земельних ресурсів, Обласний центр по гідрометеорології, Обласна санітарно-епідеміологічна станції та інші). Саме вони виступають «Відповідальними установами» $\mathrm{i}$ "Державними замовниками» спеціальних фахових регіональних цільових програм (як-то: Програма охорони навколишнього природного середовища.., Регіональна цільова соціальна програма розвитку цивільного захисту.., Регіональна програма розвитку водного господарства.., Програма «Ліси Дніпропетровщини 2015»...), де значну частину завдань пов'язано з такими безпосередніми природоохоронними заходами:

- визначення стану навколишнього природного середовища, у тому разі і радіоактивного на територіях спеціалізованих підприємств та у випадку аварій;

- дотримання сталих лімітів використання природних ресурсів, нормативів викидів і скидів забруднюючих навколишнє природне середовище речовин;

- реалізація екологічних вимог у процесі зберігання, транспортування, використання та захоронення хімічних засобів, мінеральних добрив, токсичних та радіоактивних речовин, побутових та виробничих відходів;

- прогнозування і оцінка соціальноекономічних наслідків надзвичайних ситуацій техногенного та природного характеру, мінімізація їх впливу на навколишне середовище у випадку їх виникнення;
- забезпечення готовності місцевих органів виконавчої влади та підзвітних їм сил і засобів до дій, спрямованих на упередження та реагування на надзвичайні ситуації;

- впровадження цільових програм щодо розробки і реалізації заходів регіональних екологічних програм у частині упередження виникнення надзвичайних ситуацій;

- управління в сфері водного господарства згідно з чинним природоохоронним законодавством, забезпечення потреб населення та галузей економіки водними ресурсами, виконання їх міжбасейнового перерозподілу;

- контроль щодо охорони та використання лісових ресурсів, забезпечення екологічно збалансованого ведення лісового господарства;

- нагляд за дотриманням екологічних вимог та санітарних нормативів і санітарних правил 3 охорони атмосферного повітря, водойм та водних джерел, грунтів від забруднення шкідливими речовинами для здоров'я людини;

- контроль стану об'єктів природнозаповідного фонду на землях лісового фонду та недопущення порушень природоохоронного законодавства щодо їх утримання.

Виконання регіональних цільових екологічних програм у межах установ спеціальної компетенції відбувається, окрім коштів з обласного фонду охорони навколишнього природного середовища (ОФОНПС), ще і за рахунок фінансування заходів за програмами по лінії державного галузевого загальнобюджетного розподілу. Перелік видів робіт, заходів виконання, графіки та форми проектного та підсумкового контролю затверджуються в додатках по виконанню РЦЕП Дніпропетровського обласного плану соціально-економічного розвитку в розділі «Охорона навколишнього середовища».

3 метою створення безпечних умов життєдіяльності населення, гарантування достатнього рівня безпеки території області, ефективних дій щодо запобігання i реагування на надзвичайні ситуації техногенного та природного характеру передбачено фінансування захо- 
дів РЦЕП (за напрямками програм найважливіших об'єктів) щодо конкретних екологічно небезпечних об'єктів регіону Придніпров'я:

- приведення небезпечних об'єктів виробничого об'єднання «Придніпровський хімічний завод" в екологічно безпечний стан і забезпечення захисту населення від шкідливого впливу іонізуючого випромінювання; радіаційного та соціального захисту населення м. ЗЖовті Води;

- утилізації твердого ракетного палива на Павлоградському хімічному заводі;

- вирішення екологічних проблем Криворізького гірничорудного басейну та поліпшення стану навколишнього природного середовища;

- створення і використання матеріальних резервів для ліквідації надзвичайних ситуацій техногенного та природного характерів та їх наслідків;

- захист населення території від небезпечних зсувних процесів шляхом спрямування коштів з державного бюджету на інженерний захист територій, насамперед у містах: Дніпропетровськ, Дніпродзержинськ, Кривий Ріг;

- ліквідації аварійного стану дамби №8 комплексу захисних споруд Західного басейну Марганецького родовища;

- розв'язання екологічних проблем найбільш техногенно навантажених регіонів шляхом здійснення першочергових екологічних заходів, зокрема у м. Дніпродзержинську та Криворізькому гірничорудному басейні [8].

Слід також зазначити, що частина програм була обмежена термінами 2012 , 2013, 2014, 2015 років, що постійно вимагало розробки нових програм або внесення відповідних змін у діючі програми протягом кожного 3 наступних років. Тому Департамент екології та природних ресурсів Дніпропетровської ОДА тісно співпрацює з місцевою владою над питаннями перегляду діючих програм або розробки та затвердження нових комплексних цільових екологічних програм. Отже, варто підсумувати наступне: всі вісім РЦЕП Дніпропетровської області знаходяться в активній стадії виконання і контролю за їх відповідністю щодо пріоритетних завдань на кожен рік. Фінансування поточних заходів за програмами в межах установ як загальної, так і спеціальної компетенції відбувається за рахунок коштів з обласного фонду охорони навколишнього природного середовища, за рахунок фінансування по лінії державного галузевого загально державного бюджету та частково 3 місцевих бюджету районів та підприємств.

Такий управлінський механізм реалізації РЦЕП Дніпропетровської області дозволяє загалом виконувати річні завдання в оптимальних розрахункових межах. Однак, як свідчить аналіз звітів заключних сесій Дніпропетровської обласної ради, щорічно 10\% - 15\% завдань регіональних цільових екологічних програм, профінансованих 3 ОФОНПС та бюджетів різних рівнів протягом останніх років, не виконувалися.

До висновків даного дослідження можна віднести наступне:

- метою розробки РЦЕП є проведення ефективної і цілеспрямованої діяльності з організації природоохоронних заходів органами державної влади на місцевому рівні;

- кількість та цільове спрямування РЦЕП загалом відповідають потребам на регіональному рівні і постійно оновлюються та оптимізуються;

- фінансування виконання РЦЕП знаходиться в межах $50 \%$ основних надходжень на ОФОНПС за бюджетним лімітом центру, що складає недостатню частину необхідних фінансових ресурсів для потреб екологічно проблемного регіону;

відносно низька виконавська дисципліна освоєння кощтів на виконання завдань РЦЕП свідчить про наявність порушень закону про тендерний відбір підприємств-виконавців затверджених робіт;

- загострення екологічної ситуації в регіоні значною мірою визначається недоліками старої системи державного управління природоохоронною сфрерою та існуванням об'єктивних умов для корупційних явищ, що осо- 
бливо розквітли за останні роки.

У плані практичного використання результатів дослідження в статті щодо питань вдосконалення механізму створення та ефективного виконання регіональних цільових екологічних програм, автор вважає за необхідне внести рекомендації в реалізації наступних завдань державного управління природоохоронною діяльністю на регіональному рівні:

- державним органам місцевої влади регіону більш чітко реально визначати об'єкти, обсяги та види робіт на об'єктах природоохоронного призначення, що вносяться до РЦЕП, з урахуванням поточної соціально-політичної та воєнної ситуації в Украіні;

ди $\quad \begin{array}{crr}\text { органам } & \text { місцевої } & \text { вла- } \\ \text { забезпечувати } & \text { дієвий } & \text { контр- }\end{array}$

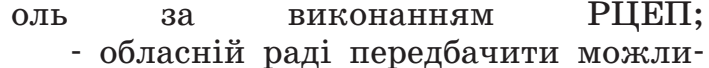
вість перегляду тендерних рішень по виконанню робіт за РЦЕП щодо підприємств-підрядчиків, що не виконують умови контрактів на проміжних етапах;

- створити реальні механізми наповнення ОФНПС та шляхи його виконання на рівні області з урахуванням поточних рішень по децентралізації влади в Україні, особливо в частині форм перерозподілу на користь регіону;

- розглянути можливість подальшого розвитку;

- звести всі закони України про охорону природи в єдиний Екологічний кодекс, що грунтувався б на європейських правових нормативах та екологічних стандартах.

\section{СПИСОК АIТЕРАТУРИ:}

1. Закон України «Про державне прогнозування та розроблення програм економічного і соціального розвитку України" : із змінами, внесеними згідно із законом від 17 трав. 2012 р. № 4731-VI. - Режим доступу : www.zakon3.rada.gov.ua/laws/show/4731-УI-2012-п.

2. Закон України «Про охорону навколишнього природного середовища» : від 25 черв. 1991

p. № 41. - Режим доступу : www.zakon.rada.gov.ua.

3. Закон України Про державні цільові програми № 4731-VI (4731-17). від 17.05. 2012 р.Режим доступу : www.zakon2.rada.gov.ua/laws/show/1621-15.

4. Перелік державних екологічних програм, відповідальним виконавцем яких є Мінекології. - Режим доступу : www.menr.gov.ua /content/article/7453.

5. Про скорочення кількості та укрупнення державних цільових програм : Постанова Кабінету Міністрів України від 22 черв. 2011 р. № 704. - Режим доступу : www.zakon3.rada. gov.ua/laws/show/704-2011-п.

6. Основні напрями соціально-економічного та культурного розвитку Дніпропетровської області на 2013 і 2014 роки : рішення обласної ради від 27 груд. 2011 р. № 193-10/VI. - Peжим доступу : www.adm.dp.gov.ua/OBLADM/Obldp.nsf/e7.

7. Основні напрями соціально-економічного та культурного розвитку Дніпропетровської області на 2013 і 2014 роки : рішення обласної ради від 27 груд. 2011 р. № 193-10/VI. - Peжим доступу : www.adm.dp.gov.ua/OBLADM/Obldp.nsf/e7.

8. Програма соціально-економічного та культурного розвитку Дніпропетровської області на 2012 рік. - Режим доступу : www.oblrada.dp.ua/official-records/social-program.

9. Програма охорони навколишнього природного середовища Дніпропетровської області на 2005-2015 роки від 24 груд. 2004 р. № 495-24/IV. - Режим доступу : www.oblrada.dp.ua/ region-programmes.

10. Про програму соціально-економічного та культурного розвитку області на 2015 рік.- $\mathrm{Pe}$ жим доступу //oblrada.dp.ua/official-records/social-program

11. Цільові програми Дніпропетровської обласної державної адміністрації. - Режим доступу//www.dnipr.dp.gov.ua

12. Арапова В. Розміщення продуктивних сил і регіональна економіка : навч. посіб. / В. Арапова / Вінницький фінансово-економічний ун-т. - Вінниця : ПП Вид-во «Тезис», 2005. $160 \mathrm{c}$.

13. Стеченко Д. М. Програмно-цільова орієнтація в управлінні соціально-економічним розвитком регіону / Д. М. Стеченко // Університетські записки : часопис Хмельницьк. ун-ту управління та права. - 2007. - № 3. - С. 167 - 172 . 


\section{REFERENCES:}

1. Zakon Ukrayiny` Pro derzhavne prognozuvannya ta rozroblennya program ekonomichnogo i social`nogo rozvy tku Ukrayiny`: iz zminamy`, vneseny`my`zgidno iz zakonom vid 17 trav. 2012 r. № 4731-VI (The Law of Ukraine On State Forecasting and Development of programs of economic and social development of Ukraine, amended by law of 17 May. 2012 p. № 4731-VI). - Access mode : www.zakon3.rada.gov.ua/laws/show/4731-UI-2012-p.

2. Zakon Ukrayiny” Pro oxoronu navkoly`shn`ogo pry`rodnogo seredovy`shha : vid 25 cherv. 1991 r. № 41 (The Law of Ukraine On Protection of the environment: 25 Jun. 1991 p. № 41). Access mode : www.zakon.rada.gov.ua.

3. Zakon Ukrayiny Pro derzhavni cil’ovi programy` № 4731-VI (4731-17). vid 17.05. 2012 r. (The Law of Ukraine On State Target Program number 4731-VI (4731-17). from 17.05. 2012) Access mode : www.zakon2.rada.gov.ua/laws/show/1621-15.

4. Perelik derzhavny`x ekologichny`x program, vidpovidal`ny`m vy`konavcem yaky`x ye Minekologiyi (The list of state environmental programs, which is the implementing Ministry of Environment). - Access mode : www.menr.gov.ua /content/article/7453.

5. Pro skorochennya kil`kosti ta ukrupnennya derzhavny`x cil`ovy`x program : postanova Kabinetu Ministriv Ukrayiny` vid 22 cherv. 2011 r. № 704 (On the consolidation and reduction of state programs: the Cabinet of Ministers of Ukraine dated 22 Jun. 2011 p. № 704). - Access mode : www.zakon3.rada.gov.ua/laws/show/704-2011-p.

6. Osnovni napryamy` social’no-ekonomichnogo ta kul’turnogo rozvy`tku Dnipropetrovs`koyi oblasti na 2013 i 2014 roky” : rishennya oblasnoyi rady`vid 27 grud. 2011 r. № 193-10/VI (Main directions of socio-economic and cultural development of Dnipropetrovsk region for 2013 and 2014: the decision of the regional council of Dec 27. 2011 p. № 193-10 / VI). - Access mode : www.adm.dp.gov.ua/OBLADM/Obldp.nsf/e7.

7. Osnovni napryamy` social’no-ekonomichnogo ta kul`turnogo rozvy`tku Dnipropetrovs`koyi oblasti na 2013 i 2014 roky” : rishennya oblasnoyi rady`vid 27 grud. 2011 r. № 193-10/VI (Main directions of socio-economic and cultural development of Dnipropetrovsk region for 2013 and 2014: the decision of the regional council of Dec 27. 2011 p. № 193-10 / VI). - Access mode : www.adm.dp.gov.ua/OBLADM/Obldp.nsf/e7.

8. Programa social`no-ekonomichnogo ta kul`turnogo rozvy`tku Dnipropetrovs`koyi oblasti na 2012 rik (The program of socio-economic and cultural development of Dnepropetrovsk region in 2012). - Access mode : www.oblrada.dp.ua/official-records/social-program.

9. Programa oxorony` navkoly`shn`ogo pry`rodnogo seredovy`shha Dnipropetrovs`koyi oblasti na 2005-2015 roky`vid 24 grud. 2004 r. № 495-24/IV (Program for Environmental Protection of Dnipropetrovsk region for 2005-2015 from Dec 24. 2004 p. № 495-24 / IV). - Access mode : www. oblrada.dp.ua/region-programmes.

10. Pro programu social`no-ekonomichnogo ta kul`turnogo rozvy`tku oblasti na 2015 rik (About socio-economic and cultural development of the region in 2015).- Access mode //oblrada.dp.ua/ official-records/social-program

11. Cil`ovi programy` Dnipropetrovs`koyi oblasnoyi derzhavnoyi administraciyi (Targeted programs Dnipropetrovsk Regional State Administration). - Access mode//www.dnipr.dp.gov.ua 12. Arapova V. Rozmishhennya produkty vny`x sy`l i regional’na ekonomika : navch. posib. (Placement of the productive forces and regional economy: teach. guidances) / Vinny`cz`ky j finansovo-ekonomichny j un-t. - Vinny`cya : $P P$ «Vy`d-vo «Tezy`s», 2005. - $160 \mathrm{p}$.

13. Stechenko D. M. Programno-cil ova oriyentaciya v upravlinni social`no-ekonomichny`m rozvy tkom regionu (Target-oriented focus in the management of socio-economic development of the region) // Universy`tets`ki zapy`sky`: chasopy`s Xmel`ny`cz`k. un-tu upravlinnya ta prava. 2007. - № 3. - P. $167-172$.

Скакальський Олександр Миколайович - магістр

Дніпропетровський регіональний інститут державного управління Національної академії державного управління при Президентові України

Адреса: 49044, м. Дніпропетровськ, вул. Гоголя, 29

E-mail: u.promeco@gmail.com

Skakal'skyj Oleksandr Mykolajovych - master

Dnipropetrovsk regional institute of public administration of National academy for public administration under the President of Ukraine

Address: 29, Gogol Str., Dnipropetrovsk, 49044, Ukraine

E-mail: u.promeco@gmail.com 